\title{
HOW SPEECH ACTS WORK IN TRANSLATION: AN ANALYSIS ON SPEECH ACTS IN TRANSLATING A SCRIPT OF TITANIC FILM
}

By:

\begin{abstract}
Arso Setyaji
Abstract

The aim of this work is to know how speech acts work in translation. It is to find out an alternative definition of translation, to know the relationship between speech acts and types of translation, and to find the possibility that speech acts are able to influence the quality of translation. Through content analysis, it is found that translation is not only the process of meaning transference but also the process of intention transference from Source Language (SL) to target Language (TL). It is also found that speech acts are in relation to types of translation. When some utterances are translated with the idea of locutionary act, the tendancy of translation type belongs to literal translation. While some which are translated with the idea of illocutionary act, it belongs to idiomatic translation. And, it is possibly true that the action of 'loss' and 'gain' belongs to perlocutionary acts. In relation to quality of translation, the use of locutionary act will perform the accuracy of meaning while that of illocutionary act will lead to naturalness or acceptability. And, the effect of illocutionary force will be realized into action by making 'loss' and 'gain'; it will increase readability.

Keywords: locutionary, illocutionary, perlocutionary, literal, idiomatic, loss, gain
\end{abstract}

\section{INTRODUCTION}

Perspective of orality versus literacy, Ong (in Hickey, 1998 p. 73) has drawn the attention to the fact that promising, responding, greeting, asserting, threatening, commanding, protesting and other so-called illocutionary acts can mean totally different things in literate culture, on other hand, and orate culture, on the other.

It is now common understanding that pragmatic meaning is not only negotiable but also across both linguistic and cultural segregates. As written by Hatim (in Hickey, 1998 p. 73), the move to develop speech-acts theory in number of directions has thus been necessitated not only by the need to look again at oral communication in face to face encounters but also by the need to attend more reflectively to textual communication precisely as 'textual'. That is to say that translation as written works can be a magnet for the attention of pragmatics studies. It is, therefore, important to study translation through pragmatic analysis.

Beginning from the statement-translation is the process of meaning transference from Source Language (SL) to Target Language (TL) - the writer is interested in studying translation in relation to pragmatics. The writer believes that it is not merely meaning that works in translation; intention--what the speaker intends--plays more important role as well. 
So, the first hypothesis of this work is that translation is the process of intention transference from Source Language (SL) to target Language (TL).

The second hypothesis, in line with types of translation, is that there is close relationship between translation and pragmatics, particularly in the employment of locutionary and illocutionary acts. When some utterances are translated in locutionary act, the tendancy of translation type is literal translation (belonging to Larson). While some others which are translated in illocutionary act, the tendancy belongs to idiomatic translation (Larson).

The third hypothesis, in relation to quality of translation, is that the employment of locutionary act will perform the accuracy of meaning while that of illocutionary act will lead to naturalness or acceptability. And, the effect of illocutionary force will create the audacity of translator to make 'loss' and 'gain'. The 'loss' and 'gain' will increase readability. The three hypotheses serve basis for this work.

\section{THEORETICAL FRAMEWORK}

\section{Translation}

Some experts have different points of view on transltion. Nida and Taber regard translation as a reproduction in TL. They (1969, p. 12) write, "Translating consists in reproducing in the receptor language the closest natural equivalent of the source-language message." Catford sees the definition of translation from a text. Catford asserts $(1974$, p. 1) translation is an operation performed on languages: a process of substituting a text in one language for a text in another. As said by Catford, it is a text which is ultimately replaced from SL to TL. Not only does Wills emphasize on the substitution of the text, but he also stresses on the content and style of the original. Wills (in Pym, 1982, p. 38) defines "Translation leads from a source-language text to a target-language text which is as close an equivalent as possible and presupposes an understanding of the content and style of the original". It is lingustically agreed that the statements of Catford and Will emphasize on the replacement of SL text into TL text. A text is a unit of language which contextually expresses meaning (Wiratno, 2003, p. 3). A unit of language consists of phonology, graphology, grammar, and lexis.

The units of languages serve a basis for types of translation. Catford (1974, p. 21), classifies types of translation into three types based on extent (Full vs Partial translation), level (Total vs Restricted translation), ranks (rank-bound vs unbounded translation). Full translation indicates that all parts of SL text are substituted into TL text while Partial 
translation signals only a part of SL text which is transferred into TL text (there is a part of SL text which is not shifted into TL text). In Partial translation there are at least two reasons: untranslatable parts (non-equivalences) and special purposes from translators to introduce 'local colour' of SL text. Different from the above types, Total Translation indicates that all language unit levels of SL text are replaced with TL materials. While, Restricted translation is signaled by the replacement of textual materials from SL into TL at one unit level onlyphonology, graphology, grammar, or lexis. The third type of translation deals with the rank in grammatical (or phonological) hierarchy.

In English grammar, a hierarchy of five units is recognized as sentence, clause, group, word, and morpheme whereas in English phonology the four units consist of tone-group (intonation), foot (or rhythmic group/stress-distribution), syllable, and phoneme. In this type, Catford (1974, p. 24-25) introduces two terms rank-bound translation and unbounded translation. Rank-bound translation occurs in the total translation; it is, however, bounded in selecting TL equivalents at one rank (or few ranks, lower in the rank scale) in the hierarchy of grammatical unit-usually at word or morpheme ranks. In contradiction of this, TL equivalence can shift freely up and down in unbounded translation. The TL equivalents are higher in the rank scale - group, clause, or sentence. Besides the above rank terms - bounded and unbounded translation, Catford also introduces three popular types: word-for-word translation, free translation and literal translation.

\section{Word-for-Word Translation}

Word-for-word translation generally means what it says: i.e. is essentially rank-bound at word-rank (but may include some morphemes-morphemes equivalences) (Catford, 1974, p. 25). In other words, this type of translation is the same as rank-bound translation-the selection of TL equivalents at one rank (or few ranks, lower in the rank scale) in the hierarchy of grammatical unit, usually at word or morpheme ranks. This type is generally used when the grammatical structure of SL is the same as that of TL. It is due to the fact that there is no grammatical change.

\section{Free Translation}

Free translation is always unbounded-equivalences shunt up and down the rank scale, but tends to be at the higher ranks - sometimes between larger units than the sentence (Catford, 1974, p. 25). In other words, this type of translation is the same as unbounded 
translation - TL equivalence can shift freely up and down in the rank scale of group, clause, sentence, or sometimes above.

\section{Literal Translation}

Literal translation is between word-for-word translation and free translation. It may start, as it were, from a word-for-word translation, but make changes in conformity with TL grammar (e.g. inserting additional word, changing structure at any rank, etc.); this may make it a group-group or clause-clause translation (Catford, 1974, p. 25). That is to say, the selection of TL equivalents is at word rank but the grammatical structure can shift at group or clause rank adjusted with the principles of TL.

\section{Example:}

SL : That boy let the cat out of the bag.

TL : $\quad$ 1. Itu anak laki-laki membiarkan itu kucing keluar dari itu tas. (W-f-W T)

2. Anak laki-laki itu membiarkan kucing keluar dari tas. (LT)

3. Anak laki-laki itu membuka rahasia. (FT)

From the reality of a text, translation, however, can be distinguished into two types: (1) literal translation which is based on the form, and (2) idiomatic translation which is based on the meaning (1989, p. 16). In other words, literal translation tends to adjust the form of SL while idiomatic translation tends to express the meaning of SL.

Literal translation is not absolute; a translator usually adjusts the grammatical form of SL with that of TL when the both are different.

\section{Example:}

I cut my-finger

Saya melukai milik saya-jari

After the grammatical adjustment, it becomes Saya melukai jari saya. Then, the idiomatic translation will be Jari saya terluka.

\section{Pragmatics}

Speech acts are central studies in pragmatics; they are the basic or minimal unit of linguistic communication. Searle (1969:16) affirms that more precisely, the production or issuance of a sentence token under certain condition is a speech act. Leech (1983:5) states that pragmatics studies the intention of utterance; asking what people intends with a certain speech act as well as entail meaning with who or to whom, where, when and how. 
According to Searle (1969:16), all linguistic communication involves linguistic acts. The unit of linguistic communication is not, as has generally been supposed, the symbol, word or sentence, but rather the production or issuance of the symbol or word or sentence in the performance of speech acts.

Austin (1996) classifies speech acts into three: locutionary act, illocutionary act, and perlocutionary act.

a. Locutionary acts

Locutionary acts are the basic meaning and the meaning refered by the utterance. According to Austin, locutionary acts are the act of speaking, such as uttering certain sound or making certain marks, using particular words and using them in conformity with the grammatical rules of a particular language and with certain senses and cetain reference as determained by the rules of the language from which they are drawn.

Locutionary act is generally defined as the act of saying. This act is the most relatively easy to recognize because it tends not to invoved context. Or, it merely refers to the meaning of utterance without invoving intention. Followings are the examples of locutionary act.

(1) "Next it'll be brandies in the Smoking Room."

(2) "I'm heading back."

Utterance (1) refers to meaning that speaker just let that they will be in the Smoking Room. The same as utterance (2) speaker said that he will be back.

b. Illocutionary acts

Illocutionary acts - the act of intending are the acts that contain an intention,. Since they are in relations to context—who talks to whom, when and where, so they are difficult to identifiy. Austin (1962: 101) called attention to the fact that acts of stating or asserting, which are presumably illocutionary acts, are characteristic of the use of canonical constantives, and such sentences are, by assumption, not performative. Leech (1983:6) explained, to identify some verbs as the signal of illocutionary acts: report, announce, ask, suggest, thank, propose, admit, congratulate, promise, compel etc. The followings are the example of illocutionary acts.

(3) "Stay where you are."

(4) "This road is slippery".

Utterance (3) could be means instruction not to come forward or to move backward. It depends on context. Utterance (4) means not only let the hearer know, but intended to suggest that he or she should be careful. 
c. Perlocutionary acts

Perlocutionary acts are the effects of what uttered by speaker, either in the form of real action or just a hope. They are so called the Act of Affecting. They are due to the fact that what is uttered by speaker has perlocutionary force to the hearer. These effects could be intentionally or unintentionally did by speaker.

\section{III.METHODOLOGY}

This work employs content analysis. Content analysis is a scientific analysis on the content of message of communication (Barcus in Noeng Muhadjir, 2000, p. 68). This technique is done to analyze data taken from 'Titanic Film, SL text and TL Text. George and Kraucer state that this technique (content analysis) is better to describe any predictability (in Noeng Muhadjir, 2000, p. 68).

\section{IV.FINDINGS AND DISCUSSION}

As mentioned in the methodology, the writer uses content analysis to analize the texts-SL and TL texts of Titanic Film. And, it is important to know that the writer see the texts from the perspective of translator when comprehending messages-there is an interaction between the writer of the script and the translator.

From the enclosed table, it is identified that there are 130 of 144 utterances including locutionary acts. While, 14 of 144 belongs to illocutionary acts. For the reason of some consideration, the writer uses Larson's categories of type of transltion to analyze some utterances as seen in table. The translation of utterances of locutionary acts tends to literal translation, while translation of that of illocutionary acts has a tendancy to idiomatic translation. Followings are some examples of utterances that are literally translated.

\section{Example:}

1. 'Don't do it' is translated into 'Jangan lakukan'. It is must be 'Jangan lakukan itu'. The translator make loss with the word 'itu', but it is literally translated, and it belongs to locutionay act since the translator merely catches from what SL says. The form of the word 'do' still exists in TL.

2. 'Don't come any closer' is translated into 'Jangan mendekat'. It is literally translated; it also belongs to locutionay act since the translator merely cacth from what SL says. The form of the word 'closer' still exists in TL. 
3. 'I mean it' is translated into 'Aku serius'. It is literally translated; it belongs to locutionay act as well since the translator merely cacth from what SL says. The form of the word 'mean' still exists in TL.

The same case happens in:

4. What do you mean no I won't? = Apa maksudmu?

5. You don't know me. $=$ Kau tak mengenalku.

6. You're distracting me.= Kau merusak konsentrasiku.

7. Go away $=$ Pergi.

8. I'm involved now $=$ Kini aku ikut terlibat.

9. I'm a good swimmer $=$ Aku perenang ulung.

10. It would hurt $=$ Memang sakit.

11. How cold? = Seberapa dingin?

12. Maybe a couple degrees over. = Mungkin beberapa derajat di bawah nol.

13. Ever been to Wisconsin? = Pernah ke Wisncosin?

14. It was an accident = Itu kecelakaan.

15. And others as seen in the table.

Now, it is true that SL utterances which are locutionarily understood by translator tend to be translated literally into TL. It will be different from the following examples that are idiomatically translated from SL into TL.

\section{Examples:}

1. 'Take my hand' = 'Ulurkan tanganmu'.

It is idiomatically translated since the translator does not pay very much attention to the form of SL. He grasps the context from what SL intends not from what SL says. Here, the writer believes that the utterance of TL 'Ulurkan tanganmu' is the result of transferring the intention of SL 'Take my hand'. It is due to the context that Jack asked Rose to give his hand to hold. It, therefore, belongs to illocutionary acts.

2. 'Stay where you are' = 'jangan mendekat lagi'

The translation is based on the context-Rose asked Jack not to come forward. So, it cannot be translated literally; it should be idiomatically translated. The translator does not focus on the form of SL. It is illocutionary act; the translator catches from what SL intends. Here the writer believes that the utterance of TL 'jangan mendekat lagi' is the result of transferring the intention of SL 'Stay where you are'. 
3. I'll let go = Kalau tidak aku akan melompat

The context of the utterance is that Rose would jump if Jack still came forward. It is idiomatically translated. The translator does not see the form of SL. He grabs hold of what SL intends. So, it belongs to illocutionary act. Here, the writer considers that the utterance of TL 'Kalau tidak aku akan melompat' is the result of transferring the intention of SL 'I'll let go'.

4. Don't presume to tell me what I will and will not do = Jangan sok tahu

It is idiomatically translated since the translator does not pay very much attention to the form of SL. He grasps the context from what SL intends not from what SL says. The writer thinks that the utterance of TL 'Jangan sok tahu' is the result of transferring the intention of SL 'Don't presume to tell me what I will and will not do'. It, therefore, belongs to illocutionary acts. The context is that Jack believed that Rose would not jump.

5. If you let go I have to jump in after you = Kalau peganganmu kau lepas, aku terjun menyelamatkanmu

It is not literally translated. The translation is based on the context that if Rose jumped Jack would jump to save her. So, it is idiomatically translated. The translator does not make out the form of SL. He grabs hold of what SL intends. So, it is illocutionary act. The writer considers that the utterance of TL 'Kalau peganganmu kau lepas, aku terjun menyelamatkanmu' is the result of transferring the intention of SL 'If you let go I have to jump in after you'.

6. The fall alone would kill you = Melompat setinggi ini. Kau pasti mati.

It is idiomatically translated since the translator does not pay very much attention to the form of SL. He grasps the context from what SL intends not from what SL says. The writer thinks that the utterance of TL 'Melompat setinggi ini. Kau pasti mati' is the result of transferring the intention of SL 'The fall alone would kill you'. It is due to the context that Jack would jump from the head of the ship.

7. I'm not saying it wouldn't = siapa yang bilang tidak.

It is not literally translated. The translation is based on the context that the jump would hurt. The translator does not make out the form of SL. He grabs hold of what SL intends. The writer considers that the utterance of TL 'siapa yang bilang tidak' is the result of transferring the intention of SL 'I'm not saying it wouldn't'.

8. No = Apa?

It is not literally translated since the word 'No' is not equivalent to 'Apa'. The translation is based on the context that Rose was somewhat angry with Jack because of his question, 
and Rose didn't know Wisncosin-what it was like and where it was. The translator knows from what SL intends. It, therefore, belongs to illocutionary acts. Here, the writer considers that the utterance of TL 'Apa' is the result of transferring the intention of SL 'No'.

9. What made you think you could put your hands on my fiancee? = Sungguh kurang ajar. Apa yang membuatmu berfikir kau boleh menyentuh tunanganku?

The translator really knows what SL intends. It is indicated that there is a gain 'Sungguh kurang ajar'. So, it can be illocutionary acts. However, it can also probably be perlocutionary act since it is an action from the translator as the effect of the utterance 'What made you think you could put your hands on my fiancee?'

10. Uh huh. That was pretty much $=$ Ya, begitulah.

An expression 'Ya, begitulah' becomes a nice equivalent for 'That was pretty much'. It is possibly due to the fact that the translator really understands what SL intends. It could be illocutionary acts and the translation tends to idiomatic.

11. Sure. Count me in = Baik, aku akan datang

It is not literally translated since the uterance 'Count me in' is not equivalent to 'aku akan datang'. The translation is based on the context that Jack is invited to come to dinner but it is not sincerely invited. It is, therefore, Jack said, 'Sure. Count me in.' The translator recognized from what SL intends. It, therefore, belongs to illocutionary acts. Here, the writer considers that the utterance of TL 'Baik, aku akan datang ' is the result of transferring the intention of SL 'Baik, aku akan datang'.

12. It was once worn by Louis the Sixteenth= Dulu milik Louis XVI

It is not literally translated since the word 'worn' is not equivalent to 'milik'. The translator wants to show that the intention of SL word 'worn' is not only 'put on' but 'possess' since to wear is not always to possess; it could be 'borrow' from someone else.. Here, the writer considers that the utterance of TL 'Dulu milik Louis XVI' is the result of transferring the intention of SL 'It was once worn by Louis the Sixteenth'.

13. To making it count $=$ Agar tiap hari berarti

It is Jack's expression after being asked by Rose's mother with a ridicule question. The question was address to the different class. Jack realized that he was not from high class but he was not as what they perceived. He could enjoy life. To show them all he said, To making it count. All of them aggred that it is well said except, Cal and Rose's mother. The writer is sure that the utterance of TL 'Agar tiap hari berarti' is the result of transferring the intention of SL 'To making it count!'. 
14. I will not be made out a fool! = Aku tidak akan kau permainkan lagi

The translation is based on the context that Calfelt that Rose as his fiancee has a fair with Jack. It is, therefore, Cal said, 'I will not be made out a fool!.' The translator recognized from SL intention that Cal was being played. Here, the writer considers that the utterance of TL 'Aku tidak akan kau permainkan lagi' is the result of transferring the intention of SL 'I will not be made out a fool!'.

\section{CONCLUSION}

It is true that there is close relationship between translation and pragmatics. The work of translation is not only the process of meaning transference but also the process of intention transference from Source Language (SL) to target Language (TL). Meaning can be grasped from what SL says, and the intention can be cought from what SL intends.

It is also true that speech acts are in relation to types of translation. The locutionary and illocutionary acts work to it. When some utterances are translated with the idea of locutionary act, the tendancy of translation type belongs to literal translation. While some others which are translated with the idea of illocutionary act, it belongs to idiomatic translation. And, some could be an idea that 'loss' and 'gain' is a written action through the process of speech acts. Since it is an action as a result of the effect of what SL says or intends, it is possibly true that the action of 'loss' and 'gain' belongs to perlocutionary acts.

By virtue of the idea above, in relation to quality of translation, the use of locutionary act will perform the accuracy of meaning while that of illocutionary act will lead to naturalness or acceptability. And, the effect of illocutionary force will be realized into action by making 'loss' and 'gain'; it will increase readability.

\section{REFERENCE}

Baker, Mona. (1991). In Other Words. London and New York: Routledge.

Bassnett, Susan. (1991). Translation Studies. London and New York: Routledge.

Bell, Roger T. (1991). Translation and Translating. Longman Singapore Publisher. Singapore.

Catford, J. C. (1980). A linguistic Theory of Translation. London: Oxford University. 
Hickey, Leo. (1998). The Pragmatics of Translation. Great Britain: Cornwell Press Ltd.

Ibrahim, Abdul Syukur. (1993). Kajian Tindak Tutur. Surabaya: Usaha Nasional.

Larson, Mildred L. (1984). Meaning-Based Translation; A Guide to Cross-Language Equivalence. Boston: University Press of America, Inc.

(1989). Penerjemahan Berdasar Makna: Pedoman untuk Pemadanan Antarbahasa (edisi terjemahan). Jakarta: Penerbit Arcan.

Leech, Geoffrey. (1976). Semantics. Middlesex: Penguin Books Ltd.

Leech, Geoffrey. (1993). Prinsip-prinsip Pragmtik (Diterjemahkan oleh Oka). Jakarta: Balai Pustaka.

Nababan, M. Rudolf. (Tt.). Aspek Teori Penerjemahan dan Pengalihbahasaan. Surakarta: Tanpa penerbit.

Nida, Eugene A. (1969). "Science of Translating”. In Pym, Anthony. 1992. Translation and Text Transfer An Essay on the principles of Intercultural Communication. New York: Peter Lang.

. (1975). Componential Analysis of Meaning: An Introduction to Semantic Structure. The Hague: The Netherlands Mouton \& Co. NV. Publishers. (1975). Language Structure and Translation. California: Stanford University Press.

Pym, Anthony. (1992). Translation and Text Transfer An Essay on the principles of Intercultural Communication. New York: PeterLang.

Samiati, Tarjana. (1998). "Masalah Makna dan Pencarian Padanan dalam Penerjemahan". Dalam Seminar Sehari di Bidang Penerjemahan, Surakarta. 
. (1999). "Makna dalam Penerjemahan". Dalam Seminar Nasional Semantik I,

Surakarta.

Sudarno, V. (1998). Penerjemahan Idiom Bahasa Inggris. Surakarta: Universitas Sebelas Maret Surakarta.

Rohmadi, Muhammad. (2004). Pragmatik Teori dan Analisis. Yogyakarta: Lingkar Media Jogja.

Rustono. (1999). Pokok-pokok Pragmatik. Semarang: IKIP Semarang Press.

Ullman, Stephen. (1962). Semantics An Introduction to the Science of Meaning. Basil Blackwell. Oxford.

\section{Enclosure:}

Table

\begin{tabular}{|c|c|c|c|c|c|}
\hline \multirow[b]{2}{*}{ No } & \multirow[b]{2}{*}{ SL } & \multirow[b]{2}{*}{ TL } & \multicolumn{3}{|c|}{ Speech Acts \& Types of Translation } \\
\hline & & & $\begin{array}{c}\text { Locutions/ } \\
\text { Literal }\end{array}$ & $\begin{array}{l}\text { Illocutions } \\
\text { / idiomatic }\end{array}$ & $\begin{array}{c}\text { Perlocution } \\
\text { s }\end{array}$ \\
\hline 1 & Don't do it. & Jangan lakukan & $\mathrm{V}$ & - & - \\
\hline 2 & Stay back! Don't come any closer! & Jangan mendekat & $\mathrm{V}$ & & \\
\hline 3 & Take my hand. I'll pull you back in. & Ulurkan tanganmu & - & V & \\
\hline 4 & No! Stay where you are. & $\begin{array}{l}\text { Tidak, jangan mendekat } \\
\text { lagi. }\end{array}$ & & $\mathrm{V}$ & \\
\hline 5 & I mean it. & Aku serius. & $\mathrm{V}$ & & \\
\hline 6 & I'll let go & $\begin{array}{l}\text { Kalau tidak aku akan } \\
\text { melompat }\end{array}$ & & $\mathrm{V}$ & \\
\hline 7 & No you won't. & & - & - & \\
\hline 8 & What do you mean no I won't? & Apa maksudmu? & $\mathrm{V}$ & & \\
\hline 9 & $\begin{array}{l}\text { Don't presume to tell me what I } \\
\text { will and will not do. }\end{array}$ & Jangan sok tahu & & $\mathrm{V}$ & \\
\hline 10 & You don't know me. & Kau tak mengenalku & $\mathrm{V}$ & & \\
\hline 11 & You would have done it already. & $\begin{array}{l}\text { Kalau serius, pasti kau } \\
\text { sudah melompat }\end{array}$ & $\mathrm{V}$ & & \\
\hline 12 & Now come on, take my hand. & & - & - & \\
\hline 13 & You're distracting me. & Kau merusak & $\mathrm{V}$ & & \\
\hline
\end{tabular}




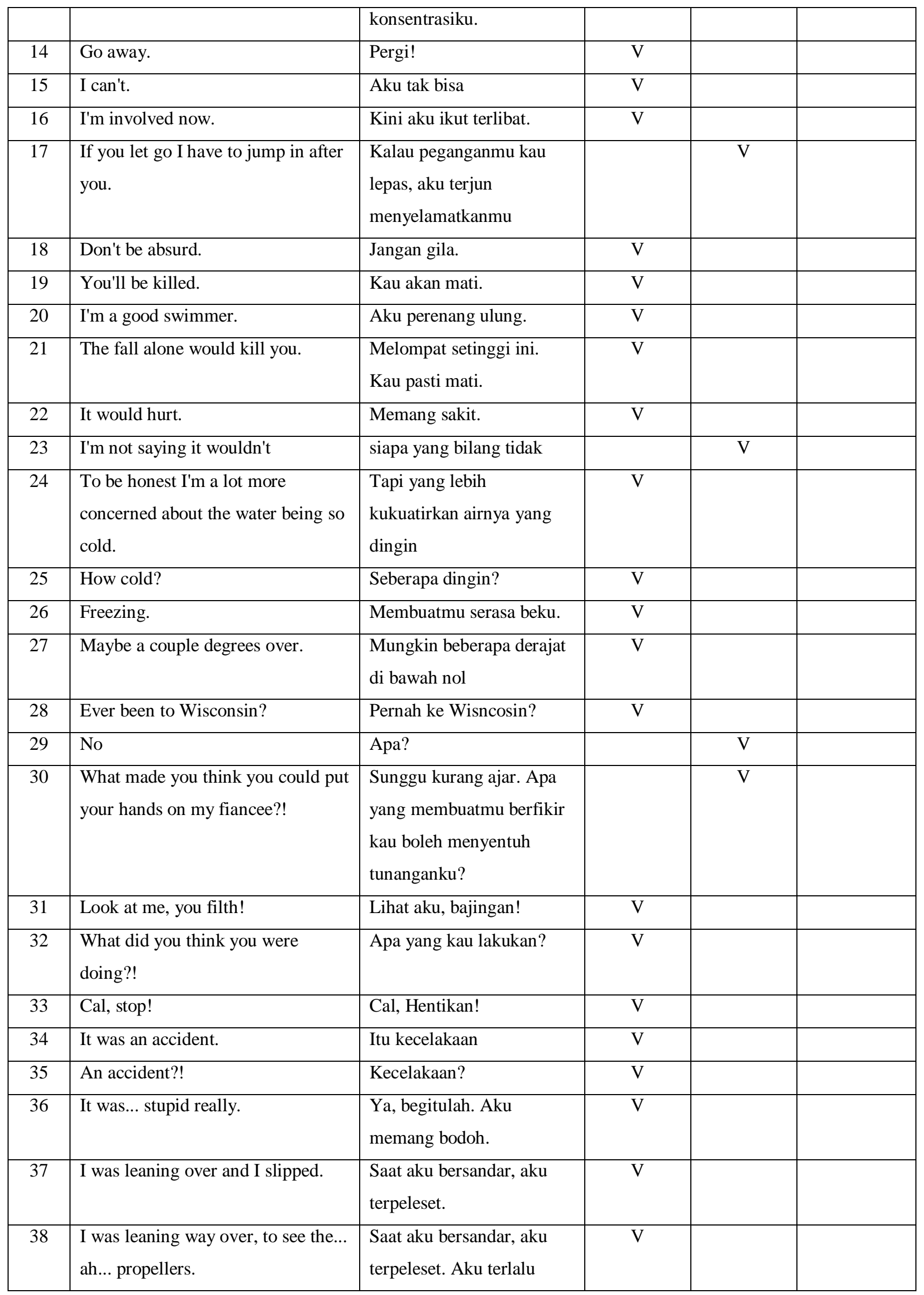




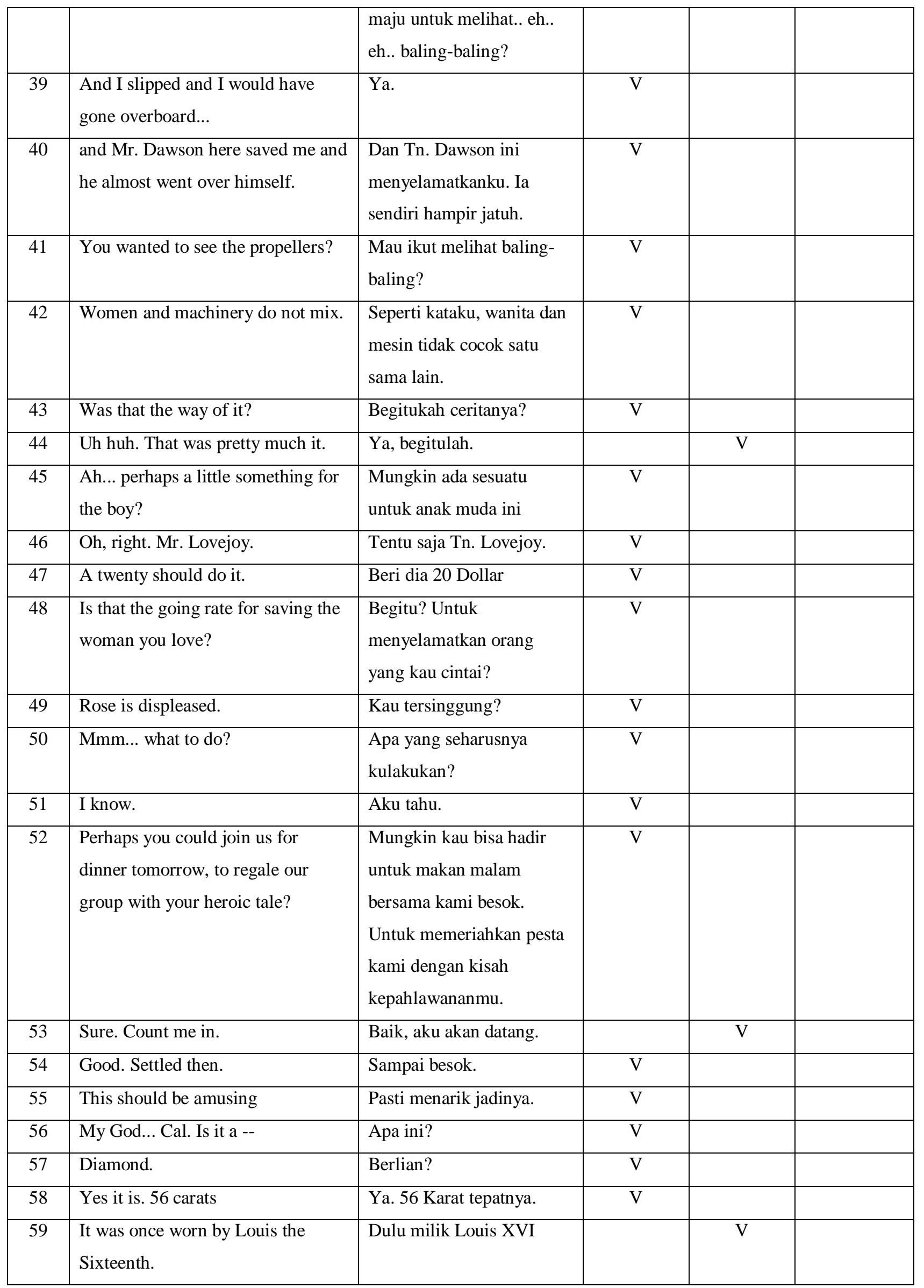




\begin{tabular}{|c|c|c|c|c|c|}
\hline 60 & $\begin{array}{l}\text { They call it Le Coeur de } \\
\text { la Mer, the -- }\end{array}$ & - & - & - & - \\
\hline 61 & The Heart of the Ocean. & Jantung Samudera. & $\mathrm{V}$ & & \\
\hline 62 & Cal, it's... it's overwhelming. & Ini berlebihan & $\mathrm{V}$ & & \\
\hline 63 & It's for royalty. & $\begin{array}{l}\text { Hanya untuk kaum kelas } \\
\text { atas. }\end{array}$ & $\mathrm{V}$ & & \\
\hline 64 & And we are royalty. & $\begin{array}{l}\text { Kita memang kaum kelas } \\
\text { atas, Rose. }\end{array}$ & $\mathrm{V}$ & & \\
\hline 65 & There's nothing I couldn't give you. & $\begin{array}{l}\text { Tak ada yang tidak bisa } \\
\text { kuberikan padamu. }\end{array}$ & $\mathrm{V}$ & & \\
\hline 66 & $\begin{array}{l}\text { There's nothing I'd deny you if you } \\
\text { would deny me. }\end{array}$ & $\begin{array}{l}\text { Apapun permintaanmu tak } \\
\text { akan ku tolak.. } \\
\text { Jika kau tak menolakku. }\end{array}$ & $\mathrm{V}$ & & \\
\hline 67 & Open your heart to me, Rose. & Buka hatimu padaku, Rose & $\mathrm{V}$ & & \\
\hline 68 & Yup. & - & - & - & - \\
\hline 69 & $\begin{array}{l}\text { That's one of the great things about } \\
\text { Paris. }\end{array}$ & Itu bagusnya Paris. & $\mathrm{V}$ & & \\
\hline 70 & $\begin{array}{l}\text { Lots of girls willing take their } \\
\text { clothes off. }\end{array}$ & $\begin{array}{l}\text { Banyak gadis disana yang } \\
\text { mau membuka bajunya. }\end{array}$ & $\mathrm{V}$ & & \\
\hline 71 & You liked this woman. & Kau suka padanya. & $\mathrm{V}$ & & \\
\hline 72 & You used her several times. & $\begin{array}{l}\text { Kau memakai dia berapa } \\
\text { kali. }\end{array}$ & $\mathrm{V}$ & & \\
\hline 73 & She had beautiful hands. & Tangannya indah. & $\mathrm{V}$ & & \\
\hline 74 & - & Lihatlah & & & $\mathrm{V}$ \\
\hline 75 & $\begin{array}{l}\text { I think you must have had a love } \\
\text { affair with her... }\end{array}$ & $\begin{array}{l}\text { Kau pasti punya kisah } \\
\text { cinta dengannya }\end{array}$ & $\mathrm{V}$ & & \\
\hline 76 & Well said, Jack. & Ucapan yang bagus, Jack. & $\mathrm{V}$ & & \\
\hline 77 & To making it count. & Agar tiap hari berarti & & $\mathrm{V}$ & \\
\hline 78 & $\begin{array}{l}\text { How is it you have the means to } \\
\text { travel, Mr. Dawson? }\end{array}$ & $\begin{array}{l}\text { Bagaimana kau punya } \\
\text { uang untuk perjalananmu? }\end{array}$ & $\mathrm{V}$ & & \\
\hline 79 & $\begin{array}{l}\text { I work my way from place to place. } \\
\text { Tramp steamers and such. }\end{array}$ & $\begin{array}{l}\text { Saya bekerja dari suatu } \\
\text { tempat ke tempat yang } \\
\text { lain. }\end{array}$ & $\mathrm{V}$ & & \\
\hline 80 & $\begin{array}{l}\text { I won my ticket on Titanic here in a } \\
\text { lucky hand at poker. }\end{array}$ & $\begin{array}{l}\text { Tapi tiket titanic ini } \\
\text { kumenangkan dalam } \\
\text { permainan poker.. }\end{array}$ & $\mathrm{V}$ & & \\
\hline 81 & A very lucky hand. & $\begin{array}{l}\text { Permainan yang amat } \\
\text { beruntung }\end{array}$ & $\mathrm{V}$ & & \\
\hline 82 & All life is a game of luck. & Hidup ini memang & $\mathrm{V}$ & & \\
\hline
\end{tabular}




\begin{tabular}{|c|c|c|c|c|c|}
\hline & & permainan keberuntungan & & & \\
\hline 83 & $\begin{array}{l}\text { A real man makes his own luck, } \\
\text { Archie. }\end{array}$ & $\begin{array}{l}\text { Tapi ada orang yang } \\
\text { menentukan } \\
\text { keberuntungannya sendiri. } \\
\text { Benar kan Dawson? }\end{array}$ & $\mathrm{V}$ & & \\
\hline 84 & $\begin{array}{l}\text { Next it'll be brandies in the } \\
\text { Smoking Room. }\end{array}$ & $\begin{array}{l}\text { Sesudah ini ada Brandy, di } \\
\text { ruangan merokok }\end{array}$ & $\mathrm{V}$ & & \\
\hline 85 & $\begin{array}{l}\text { Well, join me for a brandy, } \\
\text { gentlemen? }\end{array}$ & $\begin{array}{l}\text { Mari ikut minum Brandy, } \\
\text { tuan-tuan }\end{array}$ & $\mathrm{V}$ & & \\
\hline 87 & $\begin{array}{l}\text { Now they retreat into a cloud of } \\
\text { smoke and congratulate each other } \\
\text { on being masters of the universe. }\end{array}$ & $\begin{array}{l}\text { Kini mereka masuk ke } \\
\text { hamparan asap-saling } \\
\text { memberi selamat sebagai } \\
\text { orang terbesar di jagat ini. }\end{array}$ & $\mathrm{V}$ & & \\
\hline 88 & Joining us, Dawson? & Ikut kami, Dawson? & $\mathrm{V}$ & & \\
\hline 89 & $\begin{array}{l}\text { You don't want } \\
\text { to stay out here with the women, do } \\
\text { you? }\end{array}$ & $\begin{array}{l}\text { Kau tak ingin di sini } \\
\text { sendirian bersama para } \\
\text { wanita, kan? }\end{array}$ & $\mathrm{V}$ & & \\
\hline 90 & Actually he does, but... & - & - & - & - \\
\hline 91 & No thanks. & Tidak, terima kasih. & $\mathrm{V}$ & & \\
\hline 92 & I'm heading back. & Aku harus kembali. & $\mathrm{V}$ & & \\
\hline 93 & Probably best. & Kurasa kau baik begitu. & $\mathrm{V}$ & & \\
\hline 94 & $\begin{array}{l}\text { It'll be all business and politics, that } \\
\text { sort of thing. }\end{array}$ & $\begin{array}{l}\text { Hanya pembicaraan bisnis } \\
\text { dan politik. }\end{array}$ & $\mathrm{V}$ & & \\
\hline 95 & Wouldn't interest you. & Kau tak akan tertarik. & $\mathrm{V}$ & & \\
\hline 96 & Good of you to come. & $\begin{array}{l}\text { Dawson, senang kau ikut } \\
\text { makan malam }\end{array}$ & $\mathrm{V}$ & & \\
\hline 97 & Jack, must you go? & Apa kau harus pergi? & $\mathrm{V}$ & & \\
\hline 98 & $\begin{array}{l}\text { Time for my coach to turn back } \\
\text { into a pumpkin. }\end{array}$ & $\begin{array}{l}\text { Sudah waktunya aku } \\
\text { kembali kesisi yang lain }\end{array}$ & $\mathrm{V}$ & & \\
\hline 99 & Meet me at the clock. & $\begin{array}{l}\text { Temui aku di tangga } \\
\text { bawah }\end{array}$ & $\mathrm{V}$ & & \\
\hline 100 & You're still my best girl, Cora. & $\begin{array}{l}\text { Kau tetap gadisku yang } \\
\text { terbaik, Cora }\end{array}$ & $\mathrm{V}$ & & \\
\hline 101 & I don't know the steps. & Aku tak tahu langkahnya, & $\mathrm{V}$ & & \\
\hline 102 & Just move with me. & Ikuti Iramanya. & $\mathrm{V}$ & & \\
\hline 103 & Don't think. & Jangan Berfikir. & $\mathrm{V}$ & & \\
\hline 104 & Wait... stop! & Tunggu, Jack, Jangan Jack. & $\mathrm{V}$ & & \\
\hline 105 & $\begin{array}{l}\text { You think a first class girl can't } \\
\text { drink? }\end{array}$ & $\begin{array}{l}\text { Apa? Memangnya gadis } \\
\text { dari kelas pertama tidak }\end{array}$ & $\mathrm{V}$ & & \\
\hline
\end{tabular}




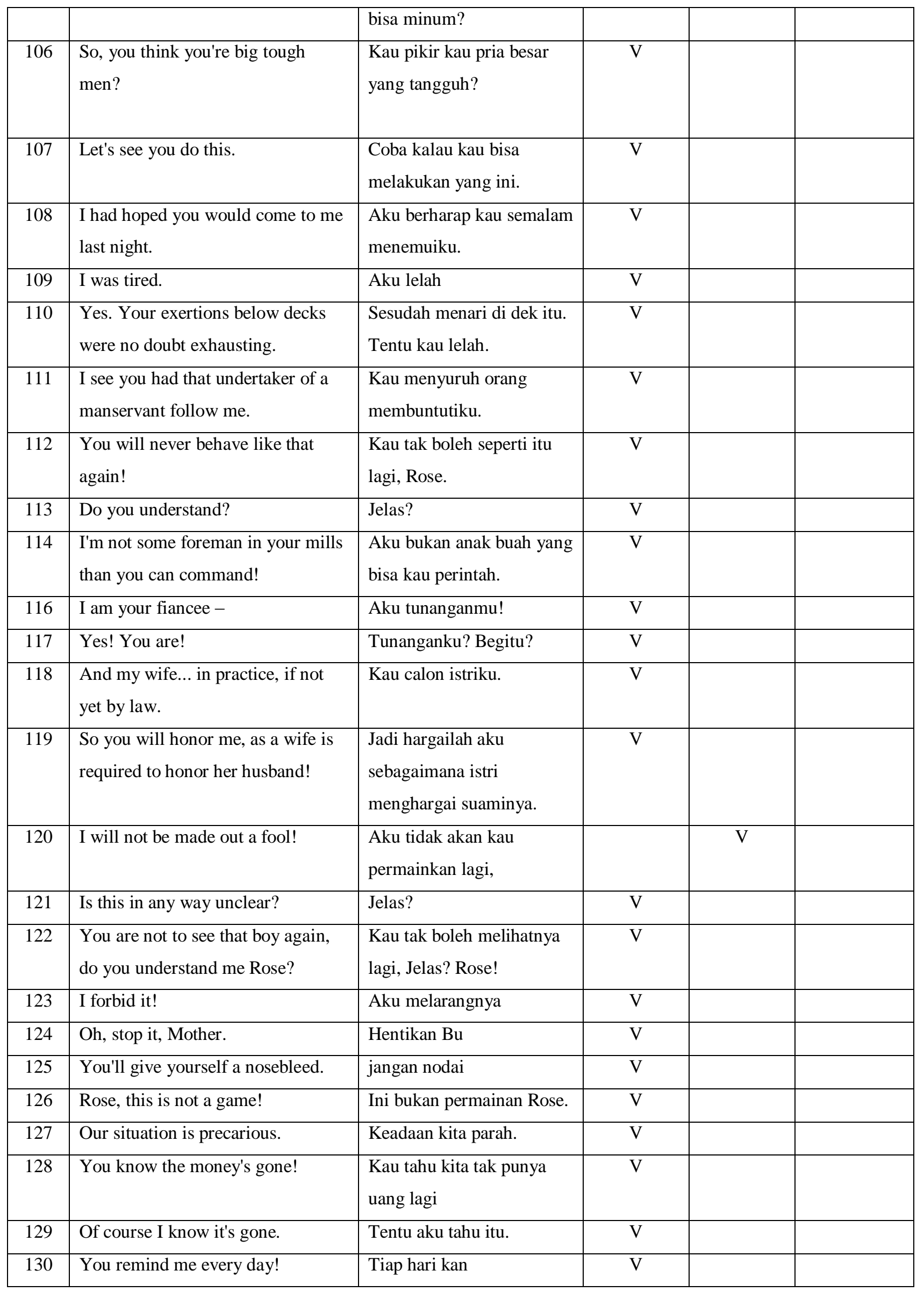




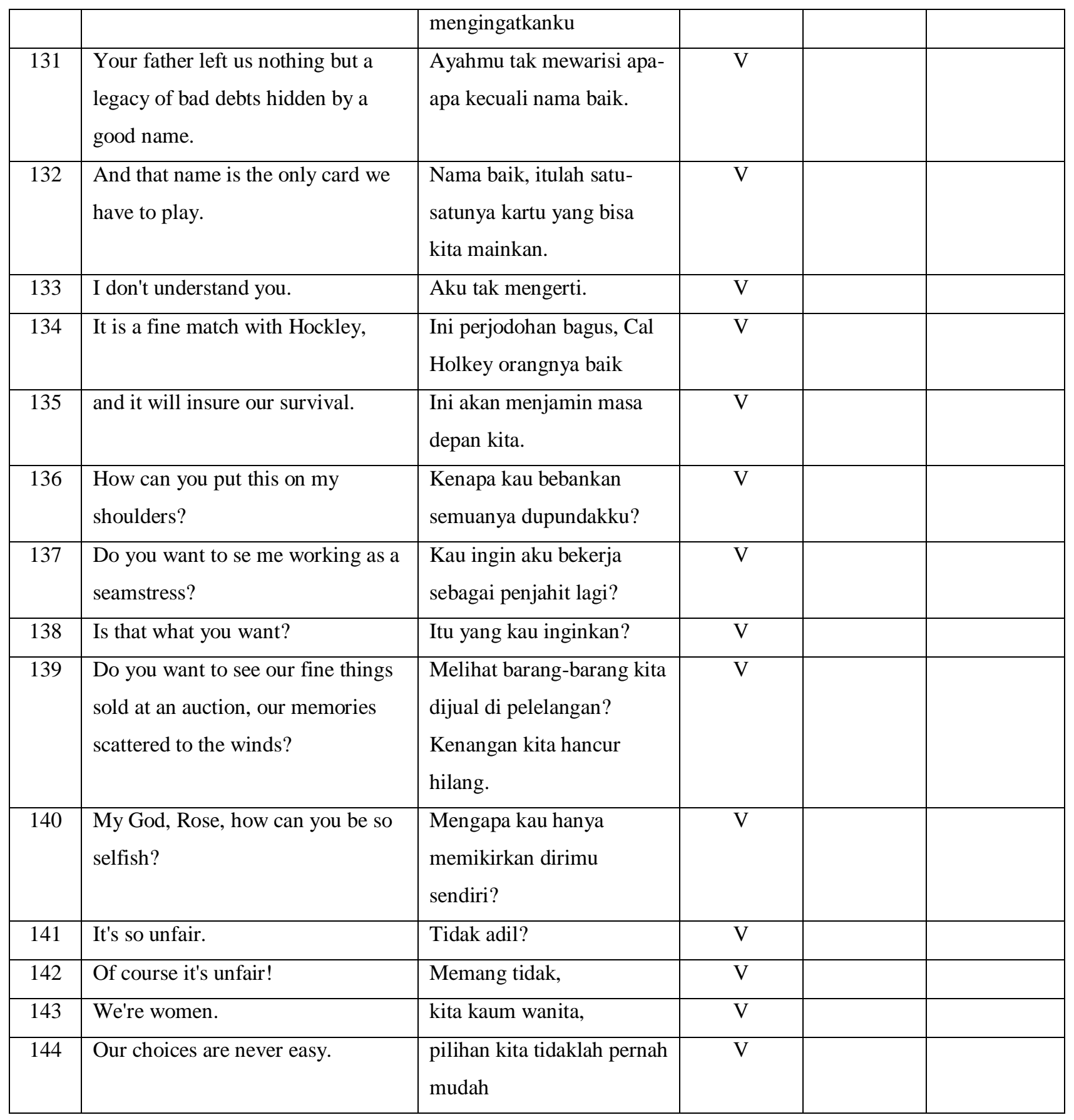

